\title{
A community-wide acute diarrheal disease outbreak associated with drinking contaminated water from shallow bore- wells in a tribal village, India, 2017
}

Kiran Kumar Maramraj ${ }^{1 *}$, G. Subbalakshmi ${ }^{2}$, Mohammed Shahed Ali², Tanzin Dikid ${ }^{1}$, Rajesh Yadav³, Samir V. Sodha ${ }^{3,4}$, Sudhir Kumar Jain ${ }^{1}$ and Sujeet Kumar Singh ${ }^{1}$

\begin{abstract}
Background: In 2016, India reported 709 acute diarrheal disease (ADD) outbreaks (> 25\% of all outbreaks). Tribal populations are at higher risk with $27 \%$ not having accessibility to safe drinking water and $75 \%$ households not having toilets. On June 26, 2017 Pedda-Guijul-Thanda, a tribal village reported an acute diarrheal disease (ADD) outbreak. We investigated to describe the epidemiology, identify risk factors, and provide evidence-based recommendations.

Methods: We defined a case as $\geq 3$ loose stools within $24 \mathrm{~h}$ in Pedda-Gujjul-Thanda residents from June 24-30, 2017. We identified cases by reviewing hospital records and house-to-house survey. We conducted a retrospective cohort study and collected stool samples for culture. We assessed drinking water supply and sanitation practices and tested water samples for faecal-contamination.

Results: We identified 191 cases (65\% females) with median age 36 years (range 4-80 years) and no deaths. The attack-rate (AR) was 37\% (191/512). Downhill colonies (located on slope of hilly terrains of the village) reported higher ARs (56\%[136/243], $p<0.001)$ than others (20\%[55/269]). Symptoms included diarrhea (100\%), fever (17\%), vomiting $(16 \%)$ and abdominal pain (13\%). Drinking water from five shallow bore-wells located in downhill colonies was significantly associated with illness $(\mathrm{RR}=4.6,95 \% \mathrm{Cl}=3.4-6.1$ and population attributable fraction $61 \%)$. In multivariate analysis, drinking water from the shallow bore-wells located in downhill colonies $(\mathrm{aOR}=7.9,[95 \% \mathrm{Cl}=4.7-$ 13.2]), illiteracy ( $\mathrm{aOR}=6,[95 \% \mathrm{Cl}=3.6-10.1])$, good hand-washing practice $(\mathrm{aOR}=0.4,[95 \% \mathrm{Cl}=0.2-0.7])$ and household water treatment $(\mathrm{aOR}=0.3,[95 \% \mathrm{Cl}=0.2-0.5])$ were significantly associated with illness. Two stool cultures were negative for Vibrio cholerae. Heavy rainfall was reported from June 22-24. Five of six water samples collected from shallow bore-wells located in downhill colonies were positive for faecal contamination.

Conclusion: An ADD outbreak with high attack rate in a remote tribal village was associated with drinking water from shallow downhill bore-wells, likely contaminated via runoff from open defecation areas after heavy rains. Based on our recommendations, immediate public health actions including repair of leakages at contaminated water sources and alternative supply of purified canned drinking water to families, and as long-term public health measures construction of house-hold latrines and piped-water supply initiated.
\end{abstract}

Keywords: Acute diarrheal disease, Outbreak, Bore-well, Tribal

\footnotetext{
*Correspondence: kiran.maramraj@gmail.com

${ }^{1}$ National Centre for Disease Control, 22 Sham Nath Marg, New Delhi 110054,

India

Full list of author information is available at the end of the article
}

(c) The Author(s). 2020 Open Access This article is distributed under the terms of the Creative Commons Attribution 4.0 International License (http://creativecommons.org/licenses/by/4.0/), which permits unrestricted use, distribution, and reproduction in any medium, provided you give appropriate credit to the original author(s) and the source, provide a link to the Creative Commons license, and indicate if changes were made. The Creative Commons Public Domain Dedication waiver (http://creativecommons.org/publicdomain/zero/1.0/) applies to the data made available in this article, unless otherwise stated. 


\section{Introduction}

Globally there are an estimated 1.7 billion cases and 2.2 million deaths from acute diarrheal disease (ADD) every year [1]. In India, the burden is particularly high with more than 13.9 million cases reported in 2016 and 709 ADD outbreaks reported accounting to more than 25\% of all outbreaks $[2,3]$.

Lack of access to safe drinking water and basic sanitation are the leading causes of ADD burden globally and in India. It is estimated that globally $58 \%$ of ADD deaths are attributed to inadequate drinking water, sanitation and hygiene [4]. The WHO/UNICEF Joint Monitoring Program for Water Supply, Sanitation and Hygiene (JMP) 2017 report revealed that 844 million people worldwide lack access to basic drinking-water service and 2.3 billion lack basic sanitation services, while 892 million still practiced open defecation [5]. The National Family Health Survey (NFHS-4, 2015-16) reported that in India only 52\% of urban households and 18\% of rural households have piped water supply, and the main source of water supply among rural households is bore-wells or tube-wells (51\%). It has been estimated that 39\% of households in India (54\% among rural households) have no toilet facility and practicing open defecation [6].

The "indigenous" populations are socially, culturally and economically isolated and usually lack access to basic drinking-water and sanitation services. Therefore, they are vulnerable to ADD outbreaks and other emerging and re-emerging diseases [7]. The United Nations estimates that there are 370 million indigenous people existing across 90 countries of the world. They constitute $5 \%$ of the world population but $15 \%$ of the poorest [8]. India alone houses more than 705 such indigenous groups termed as Scheduled Tribes. As per the Census 2011, the total Scheduled Tribe population of India is 10.43 crore with a significant proportion of them living in rural areas [9].

On June 26, 2017, Kama-reddy district of Telangana state reported 55 ADD cases from the Pedda-GujjulThanda village. We conducted the outbreak investigation to describe the epidemiology, identify risk factors, and provide evidence-based recommendations.

\section{Methods}

\section{Setting}

Pedda-Gujjul-Thanda village is a small tribal village with a total population of 563 . The village is remotely located as an isolated community with a hilly terrain and is resource-limited with poor accessibility to sanitation and hygiene facilities. The nearest health care facility available for the residents is located at a distance of $10 \mathrm{~km}$ from the village.

\section{Case definition}

We defined a case as three or more loose stools within $24 \mathrm{~h}$ in a resident of the Pedda-Gujjul-Thanda village from June 22, 2017 to July 2, 2018.

\section{Case finding}

To find cases, we reviewed medical records of local health care facilities accessed by village residents in the nearby town. We conducted a medical camp in the village during the outbreak period for five days. We conducted a house-to-house survey in the village to find more cases, which are niether reported to health facility nor medical camp.

\section{Retrospective cohort study}

We conducted a retrospective cohort study to identify risk factors associated with illness. We defined the cohort as residents of Pedda-Gujjul-Thanda village from June 22, 2017 to July 2, 2018. Village resident was the unit of analysis. For data collection, we trained five teams of local paramedical staff. Using a pre-structured questionnaire, we collected data on demographic characteristics and risk factors related to drinking water, sanitation and hygiene. Good hand-washing practice was defined as reported washing of hands with soap and water every time after defecation and before eating. A bore-well less than 30-m-deep, as assessed from the records of village administration, was considered a shallow bore-well.

\section{Laboratory and environmental investigations}

Two stool samples were collected by the treating physician from admitted patients on the first day of hospital admission and transported to the state reference laboratory within two hours in Cary-Blair transport medium. The samples were cultured for Vibrio cholerae, Salmonella and Shigella on nutrient agar, MacConkey agar and deoxycholate citrate agar. Enteric pathogens were identified by biochemical reaction and by agglutination with anti-sera. We collected details of recent rainfall and conducted an environmental survey with household as sampling unit to assess drinking water, sanitation and hygiene practices. We assessed availability of residual chlorine in all village bore-wells and tested four of five bore-wells in the most affected colonies for faecal contamination by $\mathrm{H}_{2} \mathrm{~S}$ method in field. Water was filled up to the 'fill line' of the sample bottle and incubated at room temperature $\left(25^{0}-37^{\circ} \mathrm{C}\right)$ for $36-48 \mathrm{~h}$ and observed for colour change in the medium. A water sample was suspected to be contaminated with faecal matter, if it turned black [10, 11]. Because of limited supplies, we were unable to assess the fifth bore-well. 


\section{Data analysis}

We analysed the data to describe the occurrence of cases over time, place, and person. We calculated relative risks (RR) with 95\% confidence intervals (CI), population attributable risk percentages and conducted multiple logistic regression analysis with the dependent variables including consumption of shallow-downhill bore-well water, report of visible contaminants like mud in drinking water, illiteracy, household water treatment and good hand-washing practice. We used Epi Info version 7.2 for statistical analysis.

\section{Results}

\section{Descriptive epidemiology}

We identified 191 ADD cases (65\% females), with a village attack rate (AR) of $37 \%$ (191/512). The attack rate increased with age, with highest among $>60$-year age group (55\%) and lowest among children under-10 years (11\%) (Table 1). No deaths were reported.

In addition to diarrhea, cases presented with fever (17\%), vomiting (16\%) and abdominal pain (13\%). $72 \%$ $(138 / 191)$ cases reported to health care facilities and the medical camp conducted in the village. Among the 191 cases, 159 (83\%) had mild illness treated with oral rehydration solution; 30 (16\%) had moderate dehydration treated with intravenous fluids on out-patient basis, and 2 (1\%) with severe dehydration were admitted in the district hospital for treatment with antibiotics (metronidazole and ciprofloxacin) and intravenous fluids.

Cases started reported on June 26, 2017, with onset of symptoms from 24 June 2017. Maximum cases were reported on June 27, 2017, and no new cases were reported after June 30, 2017 (Fig. 1).

Table 1 Attack-rates in an Acute Diarrheal Disease outbreak by age and sex in Pedda-Gujjula-Thanda village, 2017

\begin{tabular}{|c|c|c|c|}
\hline & Number of cases & Population & Attack rate (\%) \\
\hline \multicolumn{4}{|l|}{ Age Group (years) } \\
\hline Children (0-9) & 12 & 105 & 11 \\
\hline Young adults (10-19) & 23 & 77 & 29 \\
\hline Adults (20-59) & 125 & 274 & 46 \\
\hline $20-29$ & 39 & 97 & 40 \\
\hline $30-39$ & 42 & 84 & 50 \\
\hline $40-49$ & 29 & 60 & 48 \\
\hline $50-59$ & 15 & 33 & 45 \\
\hline Elderly ( $\geq 60)$ & 31 & 56 & 55 \\
\hline \multicolumn{4}{|l|}{ Gender } \\
\hline Male & 67 & 246 & 27 \\
\hline Female & 124 & 266 & 47 \\
\hline Overall Incidence & 191 & $512^{a}$ & 37 \\
\hline
\end{tabular}

${ }^{\mathrm{a}}$ Out of 563 population, 512 were present during outbreak period
The tribal population in the village had four sub-tribes namely Katroth, Badhawath, Nenawath, Baromath who resided in seven geographically demarcated colonies (labelled as A to G). Katroth sub-tribe resided in colonies A, B and G; Badhawath in colonies C and D; Nenawath in colony $\mathrm{E}$ and Baromath in colony F (Table 2). Colonies $B$ and $C$ had higher attack rates (65 and 47\% respectively) as compared to other colonies (Fig. 2).

\section{Retrospective cohort study}

Among 563 village residents, 512 (91\%) participated in the study. Among the 512 participants, median age was 28 years (range $1-80$ years) with $52 \%$ females; $50 \%$ reported as illiterate with agriculture as the main source of livelihood for $76 \%$.

We analysed possible risk factors associated with ADD (Table 3). Drinking water from bore-well groundwater (vs canned water) was found significantly associated with ADD $(\mathrm{RR}=12.7 ; 95 \% \mathrm{CI}=1.8-87.4)$. However, only 32 (6\%) residents in the village used canned water and bore-well groundwater was the predominant source of water supply. Therefore, we analysed the water sources further, by location and type of bore-wells. Residents who used any of the five shallow bore-wells located downhill were significantly at higher risk $(R R=4.6 ; 95 \%$ $\mathrm{CI}=3.4-6.1)$ and deep bore-wells were protective $(\mathrm{RR}=$ $0.4 ; 95 \% \mathrm{CI}=0.2-0.9$ ). Report of visible contaminants like mud in drinking water $(\mathrm{aOR}=4 ; 95 \% \mathrm{CI}=2.1-7.6)$ and illiteracy $(\mathrm{aOR}=3.6$; 95\% $\mathrm{CI}=3.5-10.1)$ were significantly associated with illness; and household water treatment (done either by boiling or use of candle filters) $(\mathrm{aOR}=0.4 ; 95 \% \mathrm{CI}=0.2-0.7)$ and good hand-washing practice $(\mathrm{aOR}=0.2 ; 95 \% \mathrm{CI}=0.1-0.5)$ were found protective.

\section{Laboratory and environmental results}

Stool samples collected from two hospitalized cases showed no growth for Vibrio cholerae, Salmonella and Shigella on culture. Among 110 households, 100 (91\%) were available for environmental survey. Among the 100 houses surveyed, 79 (79\%) were kutcha (low quality) type, made of mud, thatch and other low-quality material. Only $5(5 \%)$ households had a designated toilet at home while the remaining 95 (95\%) practiced open defecation at a site located on the slope of the hill behind the downhill colonies B and C (Figs. 2 and 3). Bore-wells were the main source of drinking water supply for 93 (93\%) households. There were two deep borewells provided by the village administration and 17 shallow type bore-wells privately constructed by village residents. Five of these 17 (30\%) shallow bore-wells were located in colonies $\mathrm{B}$ and $\mathrm{C}$, on the downhill slope below the open defecation site. Plastic pipelines from the shallow wells were improperly installed with leakages at 


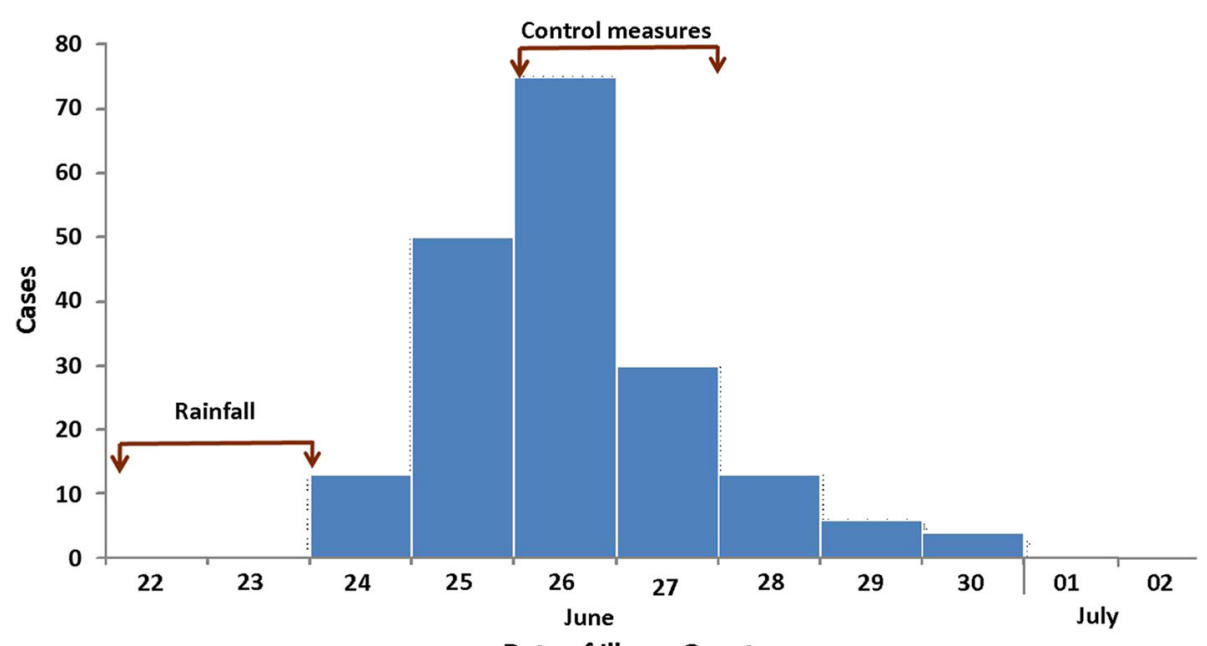

Date of Illness Onset

Fig. 1 Distribution of cases by date of illness onset in an Acute Diarrheal Disease outbreak in Pedda-Gujjula-Thanda Village, $2017(n=191)^{*}$

multiple points. There was no facility at source, for chlorination or any other mode of purification. Thirty households (30\%) treated the water before consumption either by boiling or by use of candle filters. There was no routine drinking water surveillance in place by any authority for assessing the quality and fitness for drinking water. There was no residual chlorine found in any water samples. Three of four drinking water samples from bore-wells of most affected colonies (B and C) indicated faecal contamination by $\mathrm{H}_{2} \mathrm{~S}$ field testing. There was heavy rainfall (average $65 \mathrm{~mm}$ in a day) from 22 to 24 June 2017.

\section{Prevention and control measures undertaken to contain the outbreak}

The village residents were discouraged from using shallow bore-well water and were provided with safe canned drinking water until all leakages were secured. Leakages in water supply from the bore-wells were identified and secured. Chlorine tablets were distributed for household

Table 2 Distribution of Acute Diarrheal Disease outbreak by colony in Pedda-Gujjula-Thanda tribal village, 2017

\begin{tabular}{lll}
\hline Colony & Distribution of cases & Attack rates \\
\hline B (Katroth-3) & $79(41.4 \%)$ & $65 \%$ \\
C (Badhawath-1) & $57(29.8 \%)$ & $47 \%$ \\
A (Katroth-2) & $26(13.6 \%)$ & $35 \%$ \\
D (Badhawath-2) & $9(4.7 \%)$ & $23 \%$ \\
F (Baromath) & $9(4.7 \%)$ & $17 \%$ \\
E (Nenawath) & $6(3.1 \%)$ & $13 \%$ \\
G (Katroth-1) & $5(2.6 \%)$ & $9 \%$ \\
Total & $191(100 \%)$ & $37 \%$ \\
\hline
\end{tabular}

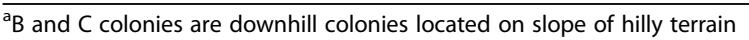

level water disinfection. We informed the residents to avoid open defecation near drinking water sources and residential premises. Public health staff conducted health education daily to improve awareness among the villagers about water, sanitation, and hygiene. After active implementation of these control measures, cases declined rapidly in the village (Fig. 1).

\section{Discussion}

A rapid systematic epidemiological investigation of this outbreak identified water contamination points and likely mode of contamination. Based on these findings and our recommendations, the local health department instituted immediate public health actions including repair of leakages at contaminated water sources and alternative supply of purified canned drinking water to families. Effective implementation of public health measures limited the exposure of the community to contaminated water source resulting in rapid containment of the outbreak.

Waterborne disease outbreaks tend to have cases spread over a time-period due to ongoing exposure to the contaminated water. In contrast, the pattern of epidemic curve in the present waterborne disease outbreak resembled that of food-borne with a point source exposure. Heavy rains contributed to the run-off of water from the open defecation site into the ground water of shallow wells located on slopes of hilly terrain resulting in heavy contamination and sudden rise of cases. Rapid control measures in the small village, implemented effectively within a short period of time, may have led to rapid decline of cases. The available epidemiological evidence also did not support generation of hypothesis of food-borne origin of the outbreak. In an outbreak reported among school children in Northern Greece in 


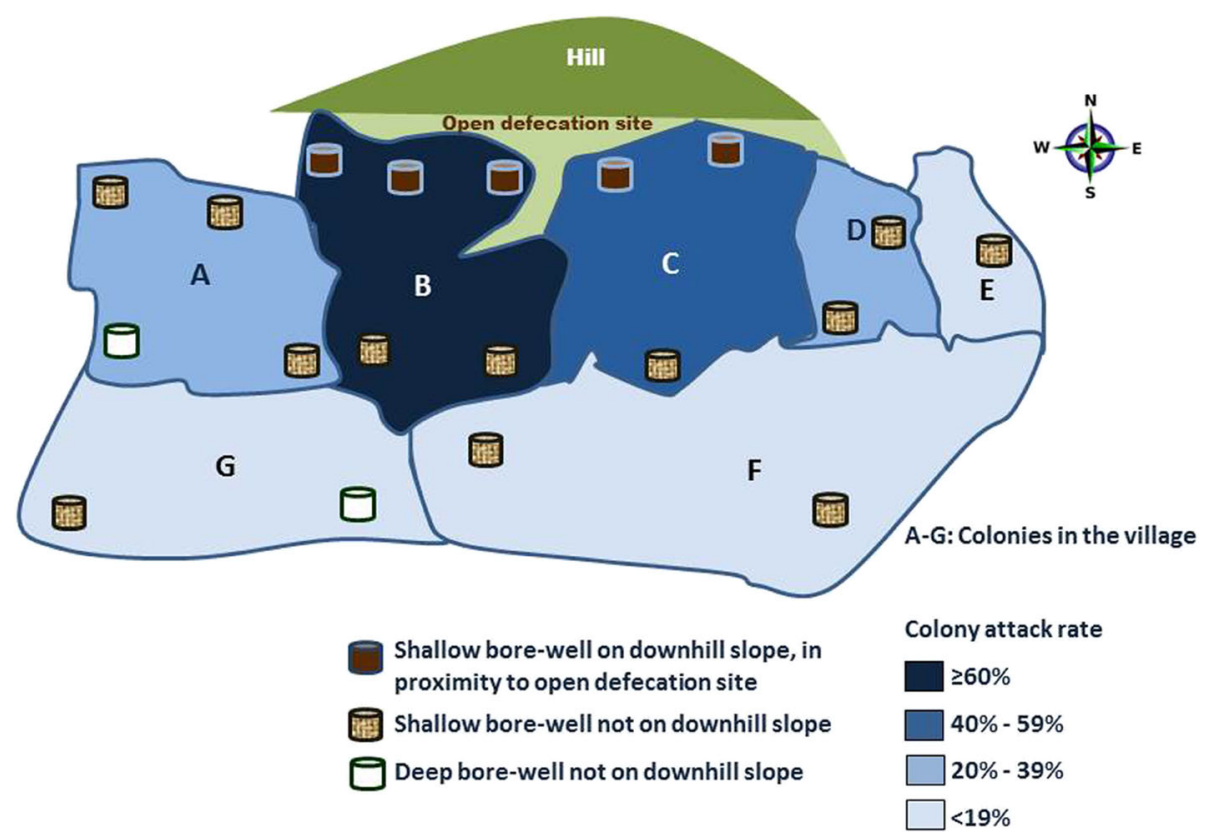

Fig. 2 Area map showing bore-wells, open-defecation site and colony-wise attack-rates in Acute Diarrheal Disease outbreak in Pedda-GujjulaThanda Village, 2017*

Table 3 Risk factors associated with Acute Diarrheal Disease outbreak in Pedda-Gujjula-Thanda tribal village, 2017 ( $n=512)$

\begin{tabular}{|c|c|c|c|c|}
\hline Risk Factor & $\begin{array}{l}\text { Attack rate } \\
\text { Exposed }\end{array}$ & $\begin{array}{l}\text { Attack rate Non- } \\
\text { exposed }\end{array}$ & $\begin{array}{l}\text { RR }(95 \% \\
\mathrm{Cl})\end{array}$ & $\begin{array}{l}\text { MLR analysis* Adjusted OR } \\
(95 \% \mathrm{Cl})\end{array}$ \\
\hline Consumption of bore-well water source (vs canned water) & 190/480 (40\%) & $1 / 32(3 \%)$ & $\begin{array}{l}12.7(1.8- \\
87.4)\end{array}$ & Excluded $^{\ddagger}$ \\
\hline $\begin{array}{l}\text { Consumption of shallow-downhill bore-well water (vs all other drink- } \\
\text { ing water sources) }{ }^{+}\end{array}$ & $149 / 224(67 \%)$ & $42 / 288(15 \%)$ & $\begin{array}{l}4.6(3.4- \\
6.1)\end{array}$ & $7.9(4.7-13.2)$ \\
\hline Report of visible contaminants like mud in drinking water & $65 / 94(69 \%)$ & $126 / 418(30 \%)$ & $\begin{array}{l}2.3(1.9- \\
2.8)\end{array}$ & $4.0(2.1-7.6)$ \\
\hline Practice of open defecation & 186/484 (38\%) & $5 / 28(18 \%)$ & $\begin{array}{l}2.2(1.0- \\
4.8)\end{array}$ & Excluded $^{\S}$ \\
\hline "lliteracy" & $131 / 252(52 \%)$ & $52 / 188(28 \%)$ & $\begin{array}{l}1.9(1.4- \\
2.4)\end{array}$ & $3.6(3.6-10.1)$ \\
\hline Kutcha house type & $174 / 457(38 \%)$ & $17 / 55(31 \%)$ & $\begin{array}{l}1.2(0.8- \\
1.9)\end{array}$ & Excluded $^{\S}$ \\
\hline $\begin{array}{l}\text { Housefly menace (Flies sighted in the house during the minimum } \\
15 \text { min-visit) }\end{array}$ & $39 / 95(41 \%)$ & $152 / 417(36)$ & $\begin{array}{l}1.1(0.9- \\
1.5)\end{array}$ & Excluded $^{\S}$ \\
\hline Recent accumulation of water in or around house & $73 / 182(40 \%)$ & $118 / 330(36)$ & $\begin{array}{l}1.1(0.8- \\
1.4)\end{array}$ & Excluded $^{\S}$ \\
\hline Use of narrow mouth container for household water storage & $29 / 80(36 \%)$ & $162 / 432(38 \%)$ & $\begin{array}{l}0.9(0.7- \\
1.3)\end{array}$ & Excluded $^{\S}$ \\
\hline Deep bore-wells (vs all other drinking water sources) ${ }^{\dagger}$ & $6 / 38(16 \%)$ & 185/474 (39\%) & $\begin{array}{l}0.4(0.2- \\
0.9)\end{array}$ & Excluded" \\
\hline Household water treatment & 24/154 (16\%) & $167 / 358(47 \%)$ & $\begin{array}{l}0.3(0.2- \\
0.5)\end{array}$ & $0.4(0.2-0.7)$ \\
\hline Good hand-washing practice & $11 / 101(11 \%)$ & 180/411 (44\%) & $\begin{array}{l}0.2(0.1- \\
0.4)\end{array}$ & $0.2(0.1-0.5)$ \\
\hline
\end{tabular}

*Multiple logistic regression analysis

${ }^{\dagger}$ Five of 19 bore-wells were shallow and located on downhill slope, in close proximity to open defecation site; and two of 19 bore-wells were deep type

EExcluded from MLR analysis due to relatively negligible sample size of residents using canned water with a very broad $95 \% \mathrm{Cl}$ in bivariate analysis

${ }^{5}$ Excluded from MLR analysis as the variable did not meet the statistical inclusion criteria $(p<0.25)$

"Excluded from MLR analysis as the variable is multi-collinear with other bore-well variables

"Less than seven-year-old excluded $(n=440)$ 

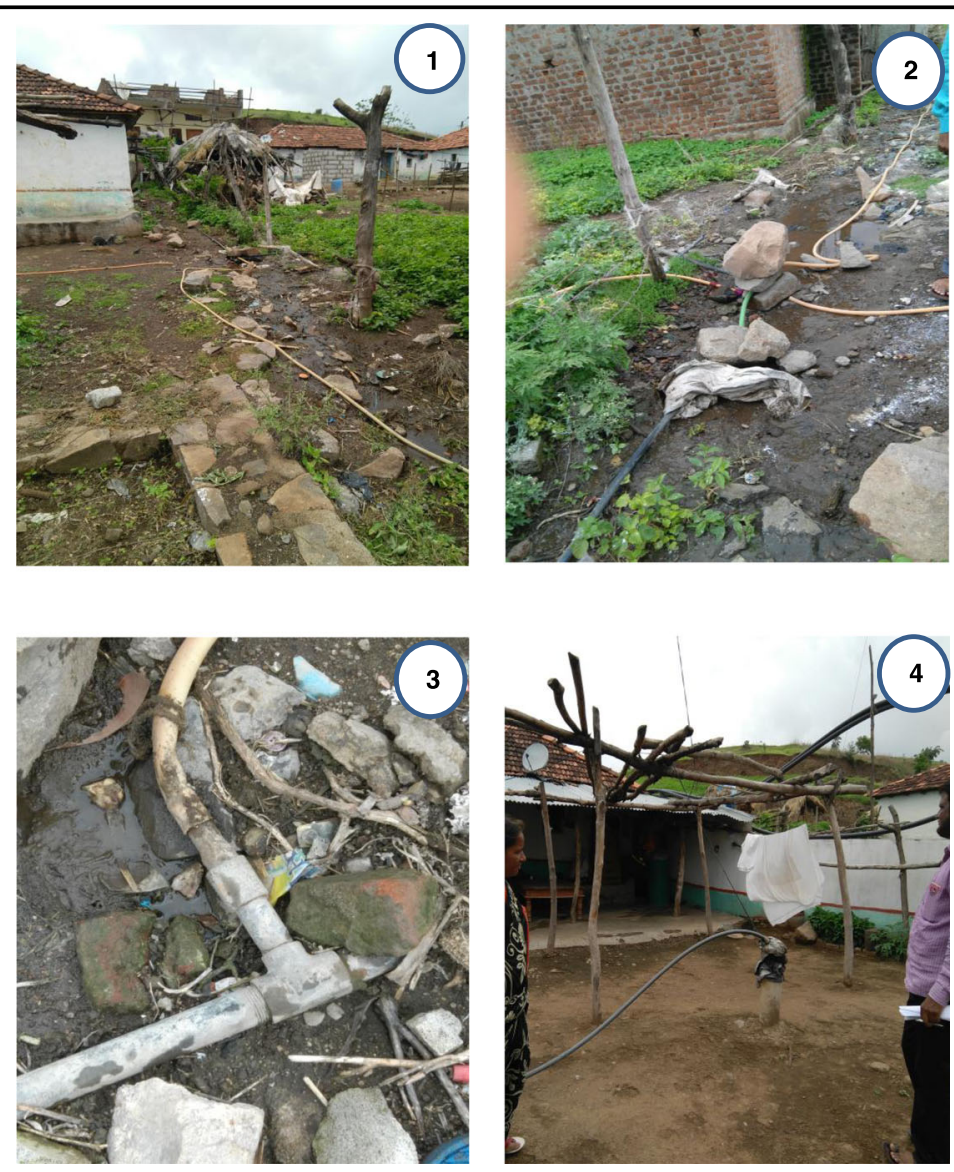

1. Runoff from open-defecation area after heavy rains, contaminating downhill borewells; 2. Contaminated shallow downhill borewell supplying water to multiple households; 3. Contaminated pipeline from Shallow Downhill Borewell; 4. Uncontaminated Secured Deep Borewell

*The photographs belong to the actual site of outbreak and were taken by the authors during investigation.

Fig. 3 Photographs of Open-Defecation site, Downhill Shallow Bore-wells and a Deep Borewell, in Acute Diarrheal Disease Outbreak in PeddaGujjula-Thanda Village, 2017*

2012, investigation revealed a waterborne viral gastroenteritis outbreak with a point source pattern, due to consumption of heavily contaminated water from a tap, which was not in use for two weeks during Christmas vacation [12].

Attack rate was high in this outbreak (37\%), possibly due to exposure to high pathogen load subsequent to gross faecal contamination of water sources. In the absence of other alternative water sources, this tribal community was exclusively dependent on the contaminated water source for drinking, therefore exposing a large section of the community to risk. Geetha et al. analysed 32 diarrheal outbreaks in south India in non- tribal communities and reported lower attack rates varying from 0.6 to $21.5 \%$ [13]. However, tribal populations in India such as in Pedda-Gujjul-Thanda are marginalized with poor availability of WASH facilities [14]. This vulnerable tribal population continues to be at higher risk for ADD outbreaks with $27 \%$ not having access to safe drinking water and $75 \%$ of households not having toilets [15]. They need special assistance schemes from the government to enable them overcome poor accessibility to WASH facilities and secure healthy living [16].

Due to inadequate availability of communally managed safe public water points by the local authority, this community in Pedda-Gujjul-Thanda village was dependent on privately constructed shallow bore-wells for water supply. These are economical but likely to be unsafe. In this outbreak, open defecation site was present on the downhill slope in proximity to the residential premises 
and water resources, increasing the risk of drinking water contamination. Among the entire village population, $61 \%$ of ADD cases were attributable to drinking water from the 'shallow downhill bore-wells' (Population Attributable Fraction 61\%), which was also evident from rapid outbreak containment following the elimination of exposure to this single risk factor. Since this exposure factor is amenable to long-term public health intervention, permanent elimination of shallow downhill borewells as water source was recommended, replacing them with properly secured deep bore-wells.

Shallow bore-wells are known for their susceptibility to contamination from surface land-use activities [17, 18]. Studies have found levels of E. coli and enteric viruses to be high in shallow sources of ground water especially when they are in close proximity to polluting sources [19-21]. Consumption of ground water from shallow bore-wells with no purification facility increases the risk of diarrhea outbreaks manifold [22, 23]. A metaanalytic study of water-borne diarrheal disease outbreaks in China reported that 78 of 85 (92\%) outbreaks (between year 1987 to 2014) were due to poor sanitary conditions of wells with lavatories/septic tanks nearby and lack of purification facilities [24]. In developed countries and urban areas of developing countries, as water supply and sanitation have improved dramatically over a period of time, such outbreaks were rarely reported in the recent past. The largest E. coli $\mathrm{O} 157$ outbreak in United States occurred in 1999 at a county fair (781 ill persons and 2 deaths) was due to groundwater source from a temporary unregulated well at the fairground [25].

Our findings have implication for India's progress towards United Nation's Sustainable Development Goal (SDG) 6 and India's nation-wide campaign 'Swachh Bharat Mission (SBM)' to ensure availability and management of water and sanitation for all. SDG 6 aims at achieving universal access to basic sanitation service by 2030; and it has been reported that between 2000 and 2017, the proportion lacking even a basic sanitation service decreased from 44 to $27 \%$ [26]. SBM aims to achieve an "open-defecation free" status in rural areas through the construction of household-owned and community-owned toilets and establishing an accountable mechanism of monitoring toilet use. In 2015 in India, around 524 million (39\%) practiced open defecation. However, under the SBM mission, due to increase in 'households with toilets' only 19 million (1.4\%) practiced open defecation in January 2019 [5, 27]. There has also been a $71.58 \%$ increase in 'households with toilets' from October 2014 to October 2019 in rural areas of the Telangana state in India [27].

The tribal community initially obstructed the effective delivery of health care services; however, after involvement of the local stakeholders and tribal leaders, the acceptance towards medical treatment and community health services improved. Notwithstanding, most of the patients were still reluctant and did not consent for giving stool specimens for laboratory diagnosis. Establishing a rapport with the reticent tribal community was a major challenge faced by the outbreak investigation team. Lack of microbiological aetiology confirmation of the outbreak remained a limitation of the investigation due to limited stool samples and laboratory-capacity constraints of the remote area.

Recognizing the pivotal importance of SDGs, national health policy of India (2017) has set the health-related cross-sectorial goal "access to safe water and sanitation to all by 2020" [28]. Greater political and financial commitment towards resource-limited remote tribal areas with effective community mobilization is required to accelerate the public health interventions to improve WASH and to prevent ADD outbreaks in the future.

\section{Conclusion}

This was a community-wide acute diarrheal disease outbreak with high village attack rate in a remote tribal village of Telangana with poor availability of safe water, sanitation and hygiene (WASH) facilities. A rapid and systematic epidemiological investigation identified drinking of faecal-contaminated water from the shallow borewells as the leading cause for this outbreak. These borewells were likely contaminated from runoff after rain from open defecation areas located on a downhill slope. Prompt and targeted public health action contained the number of cases.

\section{Abbreviations \\ ADD: Acute Diarrheal Disease; H2S: Hydrogen Sulphide; SBM: Swachh Bharat Mission; SDG: Sustainable Development Goal; WASH: Water, Sanitation and Hygiene}

\section{Acknowledgements \\ Authors acknowledge Integrated Disease Surveillance Program staff of State Health Department and Primary Health Centre Utnur of Telangana State, India. The findings and conclusions in this article are those of the authors and do not necessarily represent the official position of the State Health Department of Telangana or National Centre for Disease Control, New Delhi or Centers for Disease Control and Prevention, Atlanta.}

\section{Authors' contributions \\ KM was the primary investigator and MA was also involved in outbreak investigation. TD and RY mentored the outbreak investigation; GS, SV, SJ and SS provided administrative and technical support for the investigation. KM, TD, RY and SV were involved in revisions of Manuscript draft. All authors read and approved the final manuscript.}

\section{Funding}

There has been no specific funding for this work.

Availability of data and materials

The datasets used and/or analysed during the current study are available from the corresponding author on reasonable request. 


\section{Ethics approval and consent to participate}

The investigation was a public health response to an outbreak as part of the India Epidemic Intelligence Service Program, undertaken with the purpose to identify source of contamination for immediate control of outbreak and intended for benefit of the community at large. Ethical approval is not applicable as part of public health response. It did not involve any human laboratory sample collection for research purpose and there were no invasive investigations or medical interventions / experiments. Laboratory results of two stool samples which are mentioned in the manuscript pertain to the samples collected by the treating physician of government healthcare facility for treatment purposes.

All ethical principles and guidelines by government of India were adopted during the outbreak response. Investigation was aimed at achieving public good (beneficence) and collective welfare (solidarity), no harm done to any individual (non-maleficence), fair, honest and transparent (accountability and transparency) and participants' data was de-identified prior to analysis (confidentiality).

The outbreak response followed a two-stage process: Firstly, requisite approval was obtained from both national and state health authorities with involvement of key stakeholders from the community. Secondly, informed verbal consent was obtained from the participants after providing information about the purpose for answering the questionnaire of the outbreak investigation. As the community was mostly illiterate, participant information was provided in the presence of state health department officials, district health officer, tribal welfare officer and village / community head (Sarpanch). National Ethical Guidelines for Biomedical and Health Research involving Human Participants, Section 8, Indian Council of Medical Research Guidelines 2017 https://icmr.nic.in.

\section{Consent for publication}

Not applicable.

\section{Competing interests}

The authors declare that they have no competing interests.

\section{Author details}

'National Centre for Disease Control, 22 Sham Nath Marg, New Delhi 110054 India. ${ }^{2}$ State health department, Hyderabad, Telangana 500095, India. ${ }^{3}$ Division of Global Health Protection, United States Centers for Disease Control and Prevention, New Delhi, India. ${ }^{4}$ Division of Global Health Protection, United States Centers for Disease Control and Prevention, Atlanta, USA.

Received: 20 June 2019 Accepted: 22 January 2020

Published online: 14 February 2020

\section{References}

1. Diarrheal disease factsheet. Geneva: World Health Organization; 2017. http:// www.who.int/en/news-room/fact-sheets/detail/diarrhoeal-disease. Accessed 17 Sept 2019.

2. Integrated Disease Surveillance Program. New Delhi: Ministry of Health and Family Welfare; 2015. http://www.idsp.nic.in/index1.php?lang=1\&level= 1\&sublinkid=5803\&lid=3751. Accessed 04 May 2018 .

3. National Health Profile 2017. New Delhi: Central Bureau of Health Intelligence, Ministry of Health and Family Welfare; 2018. https://cbhidghs. nic.in/Ebook/ONS-NHP-2017-PART-I-HTML/files/assets/basic-html/page-1. html\#. Accessed 04 May 2018.

4. Preventing diarrhoea through better water, sanitation and hygiene: exposures and impacts in low- and middle-income countries. Geneva: World Health Organization; 2014. https://www.who.int/water_sanitation_ health/publications/gbd_poor_water/en/. Accessed 04 May 2018.

5. Joint Monitoring Program report: Progress on drinking water, sanitation and hygiene: 2017 update and SDG baselines. Geneva: World Health Organization and United Nations Children's Fund; 2017. https://www.unicef. org/publications/index_96611.html. Accessed 04 May 2018.

6. National Family Health Survey (NFHS-4). New Delhi: Ministry of Health and Family Welfare; 2017. https://ruralindiaonline.org/resources/nationalfamilyhealth-survey-nfhs-4-2015-16-india/. Accessed 06 June 2019.

7. Butler JC, Crengle S, Cheek JE, Leach AJ, Lennon D, O'Brien KL, et al. Emerging infectious diseases among indigenous peoples. Emerg Infect Dis. 2001;7(7):554-5.
8. Indigenous peoples and indigenous voices. New York: United Nations; 2019 https://www.un.org/esa/socdev/unpfii/documents/5session_factsheet1.pdf. Accessed 15 Sept 2019.

9. Narain JP. Health of tribal populations in India: how long can we afford to neglect? Indian J Med Res. 2019;149:313-6.

10. $\mathrm{H}_{2} \mathrm{~S}$ strip test: a water quality testing kit for bacteriological contamination. Arghyam: Indiawaterportal; 2019. https://www.indiawaterportal.org/articles/ h2s-strip-test-water-quality-testing-kit-bacteriological-contamination. Accessed 25 May 2019.

11. Water, Sanitation and Health: Evaluation of $\mathrm{H} 2 \mathrm{~S}$ method for detection of faecal contamination of drinking water. Geneva: World Health Organization; 2002. https://www.who.int/water_sanitation_health/dwq/WSH02.08.pdf. Accessed 25 May 2019.

12. Mellou $\mathrm{K}$, et al. Epidemiological investigation of two parallel gastroenteritis outbreaks in school settings. BMC Public Health. 2013:13:241.

13. Pardeshi GS, Doibale MK, Doibale MK. Profile of diarrhea outbreaks in Nanded district, India. Nat J Res Com Med. 2012;1(3):123-77.

14. Hall G, Patrinos H. Indigenous people, Poverty and Development. 2012. http://www.bvsde.paho.org/texcom/cd045364/indigenous2010.pdf. Accessed 25 May 2019.

15. India report, Census 2011. https://timesofindia.indiatimes.com/india/27-oftribal-population-do-not-have-access-to-safe-source-of-drinking-water-govt/ articleshow/63630834.cms. Accessed 25 May 2019.

16. Andermann A, et al. Outbreaks in the age of syndemics: new insights for improving indigenous health. Can Commun Dis Rep. 2017;43(6):125-32.

17. World Health Organization. Food borne disease outbreaks, guidelines for investigation and control. http://www.who.int/foodsafety/publications/ foodborne_disease/outbreak_guidelines.pdf (2018). Accessed 14 Oct 2018.

18. Guidelines on Construction \& Maintenance of Borewells and Tube-wells. New Delhi: Government of India; 2014. http://www.rdso.indianrailways.gov. in/works/uploads/File/WKS-G-2.pdf. Accessed 14 Oct 2018.

19. Sutharsiny A. et al Microbial contamination in shallow wells in limestone aquifer of Jaffna peninsula. Conference: Proceeding of Jaffna Science Association, University of Jaffna. 2009;16:01.

20. Banks, W.S.L., Battigelli, D.A., and Klohe, C.A. Occurrence and distribution of enteric viruses in shallow ground water and factors affecting well vulnerability to microbiological contamination in Worcester and Wicomico Counties, Maryland: U.S. Geological Survey Water-Resources Investigation Report. 2001;01:4147. https://doi.org/10.3133/wri014147 (2001). Accessed 17 Sep 2019.

21. Ademoroti CMA, et al. Contamination of shallow wells in Nigeria from surface contaminant migration. Environ Int J. 1987;13(6):491-5.

22. Wallender EK, Ailes EC, Yoder JS, Roberts VA, Brunkard JM. Contributing factors to disease outbreaks associated with untreated groundwater. Ground Water. 2014;52(6):886-97.

23. Harris JB, LaRocque RC, Qadri F, Ryan ET, Calderwood SB. Cholera. Lancet. 2012;379:2466-76

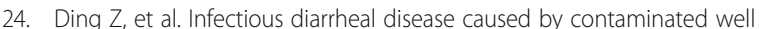
water in Chinese schools: a systematic review and meta-analysis. J Epidemiol. 2017;27(6):274-81.

25. Centers for Disease Control and Prevention. Outbreak of Escherichia coli 0157:H7 and Campylobacter among attendees of the Washington County Fair-New York, 1999. MMWR Morb Mortal Wkly Rep. 1999:48:803-5.

26. United Nations. Sustainable Development Goal 6. Ensure availability and sustainable management of water and sanitation for all. https:// sustainabledevelopment.un.org/sdg6 (2019). Accessed 14 Sep 2019.

27. Coverage status of household toilets in rural areas of Telangana state. New Delhi: Swachh Bharat Mission, Government of India; 2019. https://sbm.gov. in/sbmreport/State.aspx. Accessed 14 Sept 2019.

28. National health policy 2017. Ministry of Health and Family Welfare, India. http://cdsco.nic.in/writereaddata/National-Health-Policy.pdf (2017). Accessed 12 Dec 2018.

\section{Publisher's Note}

Springer Nature remains neutral with regard to jurisdictional claims in published maps and institutional affiliations. 